Article

\title{
Photo-Textual Relations: Emphasizing Vulnerability to Efface AIDS
}

\author{
Victoria Oana Lupașcu ${ }^{1,2}$ \\ 1 Comparative Literature Department, Pennsylvania State University, State College, PA 16802, USA; \\ vol103@psu.edu \\ 2 Asian Studies Department, Pennsylvania State University, State College, PA 16802, USA
}

Received: 5 December 2019; Accepted: 13 March 2020; Published: 13 April 2020

\begin{abstract}
This article considers the relationship between photojournalism and literature about HIV/AIDS in Romania from the late 1980s and the 1990s to examine the ways in which photo-textual relations localize and perpetuate a specific ideological understanding of the AIDS epidemic. The pictures taken by Frank Fournier in Bucharest won the Word Press Photo's first prize in 1990 and established the AIDS epidemic's image in and about Romania. Using Diana Taylor's concept of percepticide to think about what the photographs simultaneously reflect and obscure through an active training of the audience's gaze, in tandem with Lynn Mie Itagaki's theorization of visuality of vulnerability as a biopolitical heuristic, I examine the photographs performative erasure of AIDS alongside Rodica Mătușa's (semi) autobiography, Nobody's Angels. My Life Alongside Children Living with AIDS. The close-up pictures of malnourished children in a dilapidated hospital have a gritty, abrasive texture that perform a defacing function and dehumanize the central subject. The short descriptions accompanying Fournier's work, alongside Mătușa's book, present the images as illustrations and consequences of the Romanian communist regime's biopolitical measures and tie the medical emergency to the communist ideology. The texts and the photographs impose a methodology of looking, of reading and seeing as evidence of Nicolae Ceausescu's austerity measures in the late 1980s in Romania, while the centrality of infants' naked, malnourished bodies fabricate a causal relationship that obscures larger medical and cultural networks. I claim that image-text interrelations instrumentalize and localize the AIDS epidemic by visually emphasizing vulnerability as a direct result of communism, while dehumanizing and effacing the infants' and children's bodies.
\end{abstract}

Keywords: HIV/aids; percepticide; pediatric epidemic; photojournalism; autobiography

Frank Fournier, a French photographer working for Contact Press Images in the United States, went to Romania at the end of 1989 to document the pediatric AIDS epidemic in the aftermath of the fall of the communist regime in December of the same year. On 1 January 1990, a nurse is bathing "a sick child, wasting away from AIDS"1, in one of Bucharest's biggest hospitals, in what appears to be not even a half full sink of probably luck-warm, soapy water. The child's skin is loose and the rib cage is very prominent. The nurse wears protective gear while her hands provide little support to the emaciated body resting on the sink's brim. The image obscures the child's and the nurse's faces and, given the door handle in the lower left-hand side, provides a view, stolen or granted, into care practices in Romanian hospitals and orphanages in early 1990s for infants and toddlers suffering of AIDS. Fournier captured the actions mid-way, suggesting their common nature, almost banality,

1 The entire collection of photographs and their description can be found at: https://www.worldpressphoto.org/collection/ photo/1991/33408/5/1991-Frank-Fournier-GNS1-EJ (Fournier 1990). 
as well as subtly indicating the camera's own intrusion. But, the child's body's position, its emaciated appearance, and the white and black setting envelope this common action-bathing-with layers of contextual meaning speaking of poverty, abandonment, and death. The cracks in the wall around the tap, and the lack of a proper wash basin or shower facilities for bathing connote the levels of poverty and dilapidation medical institutions faced at the end of the communist regime. Moreover, the picture is de-centered and opposes an almost empty, negative space on the left side with a populated space on the right, although the focus dissipates on the child's naked body. By its position, the body appears stiff, as if rigor mortis has already set in, while the nurse is giving one last bath to a yet another AIDS patient and silently performing an improvised death ritual.

The picture above, as submitted by Frank Fournier, alongside nine other images, to the 1990 World Press Photo Contest, claims to show the magnitude of the AIDS epidemic in Romania. Fournier visited hospitals where doctor Rodica Mătușa worked (the only doctor who provided care and advocated for the HIV positive children in Romania in the 1990s and afterwards) and documented the illness of some of the same children. Mătușa's book, Nobody's Angels. My Life Alongside Children Living with AIDS and Fournier's pictures are the focus of this article, as it reads them against each other and in parallel in order to analyze the ways in which representations of the HIV/AIDS epidemic in Romania effaced the sufferers' subjectivity and instrumentalized the epidemic to comment on the communist regime's deleterious effects on Romanian society. I argue that the award-winning photographs and the (semi)autobiography become co-constitutive in emphasizing vulnerability as a direct result of communism, while objectifying the sufferers' bodies through the creation of a type of percepticide (Taylor 1997).

Diana Taylor, in the 1997 monograph, Disappearing Acts. Spectacle of Gender and Nationalism in Argentina's 'Dirty War', defines percepticide as a violent practice imposed by the government through which "people had to deny what they saw. But seeing without the possibility of admitting that one is seeing turns the violence on oneself. Percepticide blinds, maims, kills thorough the senses" (Taylor 1997, pp. 123-24). Although witnessing torture and violence on the streets, people in Argentina had, in Taylor's conceptualization, refused to know and acknowledge the ongoing violence as a means of survival. However, "seeing disrupts the comfortable not knowing," or its performance and can catalyze responsible witnessing (Taylor 2007, p. 715). The violently managed erasure of perception, of knowledge drawn from the act of seeing, if not the complete negation of seeing as an inherently epistemological act, challenges individual and collective grasps of reality as a multilayered, ongoing historical process. It proposes, instead, a fearful self-negation. In an environment not ridden by civil war or torture, I hold that percepticide, as a heuristic, refers to the construction of a partial narrative about HIV infections. Thinking of percepticide in relation to the AIDS epidemic in Romania as a way of staging and emphasizing vulnerability in relation to the communist regime while silencing competing narratives—such as HIV/AIDS as a pandemic unrelated to Ceausescu's regime, or deep seated malpractice encouraged as a means of performing one's duty-allows us to go beyond the "comfortable not knowing." ${ }^{2}$ The AIDS epidemic and the patterns of understanding it forged become apparent from photo-textual relations and are valuable epistemological tools of defining reality and our relationship to the others, to political regimes and viruses. ${ }^{3}$ By the same token, this article proposes a discussion of the relationship between visual and literary sources to underline the interweaving of visuality and agency in illness narratives, while touching on issues of effacement of bodies and entities who do not fit into the predetermined visual and intellectual category of the HIV/AIDS epidemic.

2 The "comfortable now knowing," as described by Taylor implies the concept of the "unspeakable" in Judith Butler's terms. The unspeakable, that which cannot be articulated, suggests prohibition, the stigma that keeps language and linguistic innovation at bay (Butler 2002).

3 This is also particularly relevant in relation to more recent cases of coronavirus outbreaks, such as SARS. For the relationship between visual materials and literature, and official discourse, see Ding (2014). 


\section{HIV/AIDS in Romania}

In Romania, the most publicized iteration of the AIDS epidemic was the pediatric epidemic that began via microtransfusions with HIV-infected blood to keep orphaned children alive in the second half of the 1980s. While still under the socialist regime in the 1980s, the Romanian medical system accepted blood donations as a means to obtain work permits, residence permits, visa extensions, or food. This proved to be an opportunity for the former military cadres who served in Central Africa in the 1970s, and for different other foreign nationals to donate blood in exchange for different services during a period of restrictions and food scarcity. ${ }^{4}$ With very little medicine and a preferred practice of administering any type of medication in an injectable form, with rationed electricity and hot water, but with an increased number of ill orphans, many hospitals made reusing needles a common practice when replacing absent medication with blood microtransfusions. Thus, even if the transfused blood itself was not infected, the sharing of needles used previously on children born with HIV served as an additional vector of the epidemic. The official directions prohibited doctors from reporting any AIDS cases and penalized them for every infant's death ${ }^{5}$. After the end of the socialist regime in 1989, many journalists, including Frank Fournier, traveled to Romania and uncovered the sordid conditions in hospitals and orphanages. ${ }^{6}$ International adoptions of Romanian children into the US during the 1990s also contributed to many national and international debates about Romania's pediatric AIDS epidemic, while most of the media demonized the former regime for its censorship over medical issues (When Ignorance Is Lethal 2012). The excess of media attention did not end the censorship around this issue, even after the fall of the communist regime, but conversely increased the invisibility of long-term survivors, as well as the scarcity of cultural production around this iteration of the AIDS epidemic.

In the last years of the communist regime, the country went through severe rationing of food and energy (electricity, central heating, etc.,) in order to pay in full its external debt. This, in turn, resulted in very slow, if any, modernizing processes in all existing institutions and a lack of resources that caused nation-wide discontent with the regime and brought the medical system close to collapse. ${ }^{7}$ As poverty rates increased during the 1980s, the natality law-a law that prohibited abortions and made all birth control instruments unavailable to women who did not already have four children-produced the unintended consequence of mothers abandoning their children in hospitals right after birth. ${ }^{8}$ Scant resources placed the pediatric nurses in delicate ethical positions. The choices were to either let the infants and children die as they were, or to administer microtransfusions (a daily dose of 30 to 70 milliliters of blood injected into the infants' veins) to keep the patients alive. Running water, both cold and hot, and electricity were available for only a couple of hours every day and this made proper

4 Romania sent military personnel to Central Africa in the 1970s. In the late 1980s, the military was one of the most important sources of paid blood donations. Also, donating more blood facilitated access to food and other commodities in Romania. Studies proved that HIV2, subtype F shows high prevalence in Romania, since it had active personnel in Central Africa in the 1970s. This is important because it shows that the children infected through microtransfusions lived longer in the absence of medicine, than the one infected with HIV1, generating, thus, a discourse of heroism and a more accentuated censorship from the government. For more information, see, for example Manolescu et al. (2013) and Bello et al. (2012).

5 For an extensive discussion of natality policies in Romania, see, for example Kligman (1998).

6 Frank Fournier played an important role in making the sordid conditions in orphanages in Romania visible to the world via photojournalism. He is among the first to take pictures of the HIV positive orphans and abandoned infants, and to publish them internationally in a contest organized by World Press. He won the first prize in the "General News Category." For the collection of photographs he submitted to World Press, see https://www.worldpressphoto.org/collection/photo/1991/33408/7/ 1991-Frank-Fournier-GNS1-GJ (accessed on 12 January 2019).

7 The Washington Post reported that, although Romania payed all its debt to the World Bank and to the International Monetary Fund ahead of time and made no other loans from 1981 onwards, it still owed $\$ 1.5$ billion to different countries around the world (Horne 1989). This report contradicts Ceausescu's position and the Romanian media's reports from the 1980s. See Matei (1989); Adevărul (2015).

8 Executive Order 770 from 1 October 1966 outlawed abortion under jail penalty. The only conditions under which women were allowed to have abortions were: the woman was over 45 years old; she had four children already under her care; she was severely disabled; the pregnancy was the result of rape or incest; the pregnancy presents high risks for the mother and these risks cannot be mitigated in any other way (Decret Numărul 770 1966). For more details on penalties' specificities, see Dobos (2012). For an in-depth analysis of the abortion law's impact on women and the relationship between the law and the HIV/AIDs epidemic, see Cynn (2019). 
sterilization of medical equipment largely inaccessible and prompted the use of the same syringe for all infants in one medical ward.

The first public acknowledgement of a potential pediatric epidemic in Romania dates back to 1991, after the end of the communist regime and it came from the Matei Bals Institute for Infectious Disease. Karen Dentes and Jamie Hess interpret the data offered by the Bals Institute and conclude that, in 1989, a dramatic epidemic of nosocomial [happening in the hospital] HIV infection was discovered predominantly among orphans and hospitalized children in Romania" (Popovici et al. 1991). In tandem with the Matei Bals report, one newspaper maintained: "Romania is threatened with an unusual pediatric epidemic of AIDS concentrated in crowded orphanages and clinics, spread by an old-fashioned practice of giving blood transfusions to newborn infants" (Bohlen 1990). The pediatric epidemic challenged the global perception on HIV/AIDS at the time-specifically, that it affected only the gay population (Treichler 1999) — and drew the attention to infants as a population at risk in Romania. With photographers coming from the US and France to document the very dire conditions in Romanian orphanages, and alongside the international adoption spree of Romanian children into families from the US and Western Europe, the epidemic became a known fact on the global stage despite many local authorities' denial.

Some doctors' public acknowledgement of the epidemic and the extremely difficult conditions in hospitals and orphanages came along with another realization: the infants and the children had been doubly disposed of-first, by their families and secondly, by a failing medical system overburden by poverty and censorship. The post-communist period that started in 1990 did not change much regarding the children's disposability status, but brought about national and international attention manifested by articles in The New York Times, The Boston Globe, documentaries and photographs that circulated around the world. The attention not only intensified the denial the new democratic regime upheld, but it also showed the intricate global connections and trajectories for HIV1 and HIV2. In other words, the particular structural conditions under examination in this article intertwine the biological (a particular strain of the HIV), the political (communist and post-communist modes of governance), and the cultural into a single braid, the imprint of which I will explore through an aesthetic lens, trained on specific forms of artistic practice from the 1990s and 2000s in and about Romania.

\section{Familiarizing the Unspeakable in the Hospitals}

HIV/AIDS, all over the world and especially before the advent of antiretroviral medication, dramatically changed medical care practices, and narrative strategies of representation among other phenomena. ${ }^{9}$ Doctor Rodica Mătușa, although among the very few medical doctors who were actively engaged with the seropositive children from the onset of the epidemic until the present day, openly acknowledges the ways in which fear and censorship, as well as lack of knowledge about this new virus and its manifestations, have impacted care practices until the middle of the 1990s:

Încrîncenarea lor în îngrijirea cu dragoste a unor copii străini, bolnavi, care arătau atît de rău, încit nu-ți venea nici să-i atingi, a fost una dintre primele uimiri ale noastre, ale românilor. (Mătușa 2007, p. 16) ${ }^{10}$

9 Thinking about narrative strategies of representation, James Dawes argues that "AIDS can exist for America only as a narrated disease, for it is, indeed, a disease about narration, a disease about narratives of cause (God's wrath, personal irresponsibility) and counternarratives of cause (the CIA, random affliction); about narratives of etiology (poppers, a gay lifestyle) and counternarratives of etiology (shared needles, exchange of bodily fluids). But it is also a disease about the nature of narration, about the ethical risks and imperatives of storytelling, and about the modes and the structures of language itself" (Dawes 1995, p. 28). Dawes proposes this problematization of representation in relation to HIV/AIDS earlier than Paula Treichler, although they both argue for a reinterpretation of language and modes of representation of diseases, especially after infection with HIV. I agree that during the 1980s and 1990s, when no treatment was available, writing about AIDS and its manifestations, as well as about life that has already ended and demanded mourning despite the body's presence, posed challenges to literary genres.

10 Rodica Mătușa records the children's stories in her book about their journey and her experiences during the epidemic (Mătușa 2007). 
[Their (the Americans') determination in lovingly caring for foreign, ill children, who looked so bad you did not even want to touch them, was one of the first things that amazed us, the Romanians]. ${ }^{11}$

Mătușa, in her book, Nobody's Angels. My Life Alongside Children Living with AIDS, contrasts American and Romanian medical care practices in hospitals and social homes. ${ }^{12}$ In this implicit comparison, Mătușa reveals the repulsion doctors felt in dealing with seropositive children, especially since they looked extremely malnourished and very ill. The doctors' rejection of patients is underlined through the insertion of a correlative clause with a substantial subtext: "[they] looked so bad, [so that] you did not even want to touch them." The continuation, between the lines, is "let alone anything else, such as treat them." Mătușa uses the plural, inclusive form "we" and "you" regarding the doctors to spell out her own struggles and opposes this stance with the collectivized representational unit- "copii" (children). The Romanian doctors' fear constituted a barrier in offering medical care, spelled out in the fear of touch, which echoes world-wide stereotypical attitudes regarding AIDS patients, as well as patient stigmatization, all ethically problematic. However, Mătușa, through the book, clearly states that the Americans and their practices have determined a tremendous change in the ways in which Romanians (all loosely defined and mostly regarding the medical profession) developed new ways of caring and educating parents and patients about HIV/AIDS.

The change in understanding the epidemic came with international access to databases in the aftermath of the communist regime, as well as with educational materials from the United States. Common to all epidemics, the professionals' learning curve was steep and it implied an acknowledgement of AIDS' existence in Romania, and a recalibration of the doctors' ethical and professional position regarding patients, especially children. This happened, in Mătușa's view, through international collaboration:

Noi, românii, eram contrariați la început de comportamentul străinilor, care îmbrățișau aceste aschimodii de parcă erau cei mai frumoși copii din lume. (Mătușa 2007, p. 20, emphasis added)

[We, the Romanians, were puzzled at first by the foreigners' behavior, who were hugging these extremely ugly and emaciated beings as if they were the most beautiful children in the world.]

Mătușa's use of the phrase "extremely ugly and emaciated beings" in describing the seropositive patients is telling of the environment in the hospitals, where four or more children slept in one bed. As apparent from Fournier's photograph at the beginning of this article, the children were malnourished, but their objectification through the use of the ambiguous (in Romanian) word "being" uncovers the emotional separation between doctors and patients. Moreover, the Romanian doctors faced a plurivalent challenge in addressing unfamiliar circumstances: first, the foreign doctors and volunteers entering a crumbling system and bringing help, and, secondly, a virus, obscure and with unimaginable effects on children, whose origins one could only guess in a tightly closed country before the 1990s. Thus, the use of the word "așchimodii" (extremely ugly and emaciated beings) - an old word loaned from Greek, commonly used in daily, non-academic interactions-simultaneously implies an objective description, a desire of localizing and domesticating symptoms and effects through non-medicalized, colloquial language, as well as an affective distancing on doctors' part.

The tension, though, increases with the word "hug" which describes an action determined or deterred by the beautiful and the ugly. Mătușa suggests the Americans were determined and

11 All translations are mine, unless otherwise indicated.

12 Social homes are spaces where orphaned children or the homeless are taken care of by social workers. While regimes of care can differ widely, the social homes Mătușa makes reference to became permanent homes for the seropositive infants and children and for the Romanian and foreign volunteers who took care of them. 
enthusiastic to embrace the children, despite their appearances. The beautiful, as an aesthetic category and "hug-worthy" in this case, becomes less important in performing medical care for Americans. Emotional comfort and affective care take precedence, while becoming standards in palliative care and HIV/AIDS treatments. Romania had no such standards of care and emotional support in late 1980s and 1990s. However, before negatively comparing the two methodologies of care, it is worth mentioning Melissa Cartwright's analysis of American intervention and performance of care in Romania as determined by the Cold War rhetoric and the wave of adoptions from Eastern Europe into the United States of America in the 1980s (Cartwright 2005).

Adoptions started with images, such as the one I analyzed at the beginning of this article, broadcasted into the US. A late Cold War rhetoric regarding the "waiting orphans" who needed saving from communism in Eastern Europe and Russia accompanied the images (Cartwright 2005). International adoptions were legal during Nicolae Ceausescu's regime, Romania's communist leader, and they were especially easy to perform for US citizens due to Romania's strengthening its connections with Washington against the USSR during the 1980s (ADST 2015). Following a self-imposed saving mission rhetoric, in 1990, the ABC TV station aired a documentary called The Shame of a Nation, in tandem with an episode of 60/60 talk show, both in the TV news magazine genre, emphasizing the gruesome conditions in Romanian orphanages and issuing a call for Americans to save the children by adopting them (20/20 Romanian Orphanages 2017). According to the US Ambassador to Romania at the time, Virginia Young, more than a thousand infants and children received visas as a result of adoptions into the US in 1990 (ADST 2015). This wave decreased in energy when it became clear that the children were HIV positive, hepatitis B positive, and had physical and psychiatric disabilities. ${ }^{13}$ Despite a large number of children receiving medical visas to be studied and "helped" in the US, the HIV/AIDS epidemic took over the news and put a brake on the international adoption fever, but not on humanitarian interventions into Romania. During these interventions, as described by Mătușa, US nationals brought in supplies (some necessary and some unnecessary) and a routine of care unfamiliar to Romanian doctors (Mătușa 2007, p. 11). Performing care by hugging emaciated children, regardless of their appearance, changed perception of AIDS in hospitals, the interactions between doctors and patients, and materialized what Cartwright calls the "politics of pity" into pedagogical endeavors of care during an epidemic (Cartwright 2005).

In this respect, American volunteers and doctors have made an impact in the ways in which doctor Mătușa and her colleagues reformed their practices.

Se schimbase însă complet felul de îngrijire a copilului. Nu mai era privit ca un bolnav sau ca un orfan, ci ca o fetiță sau un băiat care are o 'mamă', căruia i se dă să mănînce normal, care este educat și căruia i se formează deprinderi corespunzătoare vîrstei lui-un copil care trăiește într-o «familie », nu într-un spital." (Mătușa 2007, p. 14)

[Taking care of a child underwent a complete change. You would not see them as ill or orphans, but as a little girl or a little boy who had a 'mother', who was fed normally, educated and helped to develop age appropriate habits-a child who lives in a 'family', not in a hospital.]

While introducing the concept of "social family" and the idea that seropositive children can be regarded as any other patient, Mătușa depicts the internal and external negotiation of one's own subjectivity and ethical position in relation to the epidemic and the patients. The doctor, juxtaposing

13 There are many accounts in which journalists and scholars critique the black-market adoptions from Romania, but the scrutinizing eye focuses on Romania's poverty, lack of morals and mistreatment of women and children. The critique does not extend to American couples who took advantage of these conditions and picked and chose or even ordered an infant to bring to the United States. Such titles include: The Romanian Baby Bazaar (Hunt 1991); Secret Suffering of Ceausescu's Babies: The Plight of HIV-Positive Orphans in Romania (Gillie 2019); Forgotten Children: What Romania Can Tell Us about Institutional Care (Nelson et al. 2014). 
the Romanian and American physicians and volunteers, makes an important point about the AIDS epidemic. Specifically, she shows that one nation, one group of doctors or one medical system cannot cure, handle, or hide an already highly sensitive and epistemologically resistant topic such as AIDS. Such an understanding, especially when stigmatization and fear abound, comes only from collaboration and from reframing one's ethical position in relation to what is foreign, scary, and ugly. Moreover, Mătușa's narrative carefully encompasses the intricate geopolitical position Romania found itself at the end of the 1990s and describes the changes in medical practice as they happened through and because of the HIV/AIDS epidemic. Nonetheless, Romania's image as lacking resources and knowledge, and the United States of America's position of "bountiful and knowledgeable" replicate Cold War rhetoric and the politics of pity articulated as a critique of humanitarian and United States' political interventions in developing countries.

While these tensions are at play in Mătușa's text, the (semi)autobiography corroborates attitudes and discourses related to diseases and sickness that will define the medical profession in the next few decades. The narrative, concise and direct, articulates the shift in doctors' mentality and practice as determined by national and international narratives around HIV/AIDS: from a refuse or intense reluctance to touch the children to embracing them and perceiving the infants as part of one or more social networks. Thus, performing care and narrating care instantiate attempts of domesticating the "unspeakable" (Butler 2004) in hospitals and society at large.

\section{Training Readers}

Nobody's Angels comprises thirty-three short vignettes that educate and train the reader alongside the doctor. An autobiography, as much as a memoir, the book positions itself at the intersection of two genres and uses storytelling as its main technique of exposition. It creates a collage of stories, very much in the vein of the medical file, that shows a progression from fear and lack of hermeneutic tools for understanding reality as the AIDS epidemic set into a change in care practices and the epidemic's characterization. The stories are very short, a few pages maximum, and metonymically replicate the speed at which the children died. The accumulation of details and knowledge from one story to another builds an interstitial space where the unspeakable could be re-imagined so that it becomes familiar and can be interpreted through common words. With each story, the image of the "very ugly and emaciated child" changes and becomes a picture of "a normal child," described with realist tools. This progression does not happen with photojournalism where the fixity of the image limits the descriptive power of the photograph's elements, such as color, position of the subject, angle, and focus.

The book performs a pedagogical function through its realist approach to representing the AIDS epidemic. Realism, as a genre, in this case "refers less to the narrative mode itself, than to the mandate to represent the underlying 'truth' of the situation," as Magalí Armillas-Tiseyra argues about the dictator novel and its use of realism. ${ }^{14}$ The "truth" as a learning process that negotiates the meaning of life in the AIDS wards and in orphanages during both the communist regime and its immediate aftermath assumes a labored position — it implies the acknowledgement of vulnerability as an ontological, shared condition of life during and in the absence of an epidemic. The stories perform doctors' refamiliarization with their patients as a means of containing public perceptions on AIDS and redefining acts of care in a medical emergency that characterized profound transformations in Romanian, postcommunist society. However, the underlining conditions that drive the narrative rely on a constant comparison between Romania and the United States of America, or, later in the narrative, Japan.

14 Here, I am not developing an analogy between the doctor and the dictator, but I am underlying the function of realism in works where writing is part of working thorough a type of trauma, and its role in portraying medical emergencies, conditions of precarity and their influence over what the doctors experienced in hospitals and described in their writings. For an in-depth analysis of realism's role in the dictator novel, see Armillas-Tiseyra (2018). 
HIV/AIDS marked a watershed moment in the medical profession and it left profound marks on the cultural understanding of globalization and human life's position inside systems of neoliberal medicalization of everyday life. ${ }^{15}$ The epidemic, through its magnitude, lengthy duration, and political implications, became a lens through which the communist regime could be understood, its ills crystalized in the opportunistic infections and lack of medicine.

Aproape toți părinții interesați de soarta copiilor lor ne acuză pe noi, cadrele medicale, de năpasta care s-a abătut asupra lor. Foarte greu îi poți face să accepte că așa a fost sistemul, că în toate domeniile erau lipsuri, privațiuni, neputință și neștiință, nu numai în sectorul sanitar. (Mătușa 2007, p. 36)

[Almost all the parents, who were interested in their children's fate, accused us, the doctors, for their tragedy. It was very hard to convince them to accept that the system was like that, that not only the medical system but every profession lacked resources, had its shortcomings, its lack of possibilities and knowledge.]

Doctor Mătușa negotiates the tension between physicians and parents' blame in showing how vulnerability becomes an ideological result of communism. As a political regime and an economic system, Nicolae Ceaușescu's communist regime intensified its grip on society and imposed rationing of food and energy so that it could claim its economic and political independence from the World Bank and International Monetary Fund. Despite the grandiose goal, this attempt, successful to a high degree, made the population and the medical system vulnerable to poverty, and increased disease rates. Mătușa refuses to accept the blame and proposes a comprehensive view of the entire Romanian social, political, economic, and medical systems that shows how structural conditions determined the spread of HIV in orphanages and pediatric hospitals. While doctors and nurses had not sterilized the needles, the national medical system did not implement a policy to test the blood they used for microtransfusions. This differential view is better described as a methodology of looking by Sturken and Cartwright (2009). In my conceptualization this differentiated view not only instrumentalizes the AIDS epidemic and transforms it into a tool of analyzing larger social and political compounds taking energy away from the children's fate and suffering processes, but also naturalizes the epidemic as yet another tragedy in a chain of tragedies. The naturalization leads to percepticide-a type blinding that glosses over suffering and the interweaving of the social, political, and cultural in the making of the epidemic.

While the narrative in Mătușa's work offers a way of looking and thinking about the epidemic, Frank Fournier's collection of pictures furthers the discussion by bringing up the tension between containment, agency, and seropositive bodies. The images extend Mătușa's position while raising questions regarding practices of documenting the epidemic and creating recognizable visual patterns. Lastly, the infants' effacement starts to materialize when their precarious conditions become the reasons for Fournier's travels and, thus, their pain is inscribed in an international repertoire of suffering during the AIDS epidemic.

\section{Containing the Epidemic through Images}

Frank Fournier, in an interview for the documentary After the Fall: HIV Grows Up directed by Frederick Taylor in early 2000s, reminisces about visiting the hospitals where doctor Mătușa worked and photographing the children and infants she was working with. This connection offers a multifaceted approach to framing the environment in the hospitals, the children and the epidemic itself. Doctor Mătușa paints a concise picture through clear descriptions and use of plain, common language which localizes the AIDS epidemic inside a cultural tradition ridden by fear and stigmatization, while Fournier's photographs provide a visual tool of containment.

15 This view finds support in works by Treichler (1999). See also Sturken (1997). 
Positioning epidemics and diseases inside a frame represents an intellectual and affective mechanism of engagement. Sander Gilman holds that:

Our examination of the image of the sufferer provides us with rigid structures for our definition of the boundaries of disease, boundaries that are reified by the very limits inherent in the work of art- the frame of the painting, the finite limits of the stage, the covers of the book, the perspective of the photograph, or the narrative form of the novel. (Gilman 1988, p. 2)

Sander proposes that the physical limits of the work-of-art, in this case photography, offer the illusion of the epidemic's boundaries, giving us, thus, a manageable epistemological piece of information to reckon with. Limiting an epidemic, or a pandemic, becomes a cultural and intellectual process of containment that transforms the epistemologically obscure medical phenomenon into social reality. From this position, photography represents a heuristic for understanding the effects and workings of the human immunodeficiency virus. By representing vulnerability and making it visible, Fournier's photographs supplement doctor Mătușa's descriptions in a controlled manner, and attract the identification between the image and the word "așchimodii" (the very emaciated and ugly beings). A visual definition of the word highlights the photo-literary connection and contributes to the formation of a repertoire of representations of AIDS patients and their appearance in Romania. ${ }^{16}$ However, the strong emphasis on the pediatric epidemic — the images, the literature, the documentaries, the TV shows, and the international attention-determines a type of percepticide to all the other instantiations of the HIV/AIDS epidemic for the hemophiliac population, the gay and lesbian population and the group of drug users in Romania, just to name a few.

The photographs, through their fixity, and despite their performative and metaphorical containment of the epidemic, instantiate a punctual visual commentary, a visual quotation (Sontag 2004, p. 85), and do not withstand a temporally elongated engagement with their subject. While Fournier's photos show emaciated children waiting to die, their death is only implied. For example, the picture from the beginning of this article may or may not portray a corpse being washed in preparation for burial. The ambiguity undermines the ontological fixity of the picture, as described by Gilman, and gestures toward larger cultural and socio-economic structures. Simultaneously, with this failed, yet hermeneutically productive, attempt of containment and illustration, the pictures become unstable means of acknowledgement that "the process of representation is inherently incomplete, and thus inevitably political" (Bleiker and Kay 2007, p. 141). Moreover, Fournier publishes his photographs against an international background where the lines between images of "the waiting social orphan" (Cartwright 2005) from former socialist/communist countries and the "child dying of HIV/AIDS" are increasingly blurred in international media. They reinforce a static picture of the epidemic and "strengthen the perception that the disease is not part of the daily life, but something less real and more remote" (Bleiker and Kay 2007, p. 144). Thus, Fournier's portfolio creates a repertoire (Taylor 2007) of AIDS images; incomplete, ethically problematic, but heuristically useful in understanding, in small increments and in fixed contexts, the unspeakable.

The visual repertoire has another function: to document. If we look at Fournier's works from the perspective of the medical photographic genre, the nine images he compiled stand in for an archive of the pediatric epidemic, of the effects of AIDS on toddlers' and infants' bodies, as well as of the material conditions inside hospitals at the time. In a similar gesture to Mătușa's photographs encompassed in the (semi) autobiography, the photographs are not exclusively portraits, as many times is the case in medical photography (Sheehan 2011).

In this regard, Fournier and Mătușa are synchronous in their practice with Gideon Mendel's techniques of photographing people living with HIV, namely departing from a visual emphasis on

16 I draw on Diana Taylor's conceptualization of the archive and the repertoire (Taylor 2003). 
the face and leaning more toward a landscape-type of photograph that challenges stereotypes and attempts to offer a more nuanced description of the epidemic (Mendel 2008, pp. 80-82). While not adhering completely to the medical photography genre because of the distancing from the portrait technique, Fournier's collection provides a limited number of nuances since the visual trajectory only covers the road from emaciation and suffering to death. However, the documentary valence and limited narrative trajectory of the photographs transform Fournier's work into what Douglas Crimp calls "phobic images" (Crimp 1992, p. 130; also Engelmann 2016). In other words, the dramatic display of naked, emaciated bodies produces a "reassurance that the person with AIDS is detectable, not invisible or among 'us'" (Sturken 1997, p. 153). Moreover, the photos serve "in an outside the clinic as visualization of the unusualness and uncertainty that was caused by the emergence of the epidemic" (Engelmann 2016, p. 253). In this manner, and drawing on Engelmann, the photographs reflect the environment around the people living with AIDS, as much as they offer a recognizable narrative of recognition of the epidemic's ontological challenges posed to a perceived future through the visualization of AIDS. This sort of containment, as well as the potential stereotypical recognition of children living with HIV provided by these images, contribute to the documentary impetus in Fournier's work and undercut its attempt of representing multiple stages, bodies, and conditions in and over which the epidemic exerted its influence. Lastly, the pictures taken by Fournier, sterile in their black and white background, contrast with Mătușa's plethora of medical and non-medical pictures meant to memorialize, to pin down names and images that needed to be remembered, rather than document in a bureaucratic manner.

\section{Visuality and Agency}

Across the field of medical humanities, critical medical humanities and narrative medicine, representations of suffering have always posed questions regarding the patients' agency, the right to look (Mirzoeff 2011) and the angle of looking, as well as regarding the responses such representations-literary or photographic - engender from their audiences. The descriptions accompanying Fournier's photographs tell the audience they are looking at Romanian AIDS victims, children on the verge of death. However, if it were not for the captions, it would be less likely for the spectator to know the children were Romanians, that the time was 1 January 1990, and that the political regime was a nascent democracy in the aftermath of the fall of communism. By providing such details, children become the "face" of the epidemic in Romania, the victims of communism, visibly vulnerable. The photographer does not provide names or any type of details about the infants and children themselves, but emphasizes the political milieu at the time. Thus, the subjects of the photographs become objectified and the images stand in for instruments of political critique that forego, or construct at best, empathy.

Following Boltanski's interpretation of Hannah Arendt's conceptualization of pity, this article agrees that the photographs, as well as Mătușa's (semi)autobiography, "view the unfortunate collectively, even though [they] rely on singling out particular misfortunes to inspire pity in the first place" (Boltanski 1999, p. 4). Fournier's camera, with its inherent intrusive nature, displays the children in a rather passive way, much like Hooper in the book Slim: A Reporter's Own Story of HIV/AIDS in East Africa (Hooper 1990) displayed his subjects in representing AIDS in Africa in the 1990s. Just like Hooper, Fournier's work "is an attempt to capture the universal nature of death, stripped free of culture and context. As a result, it shows an image of passive victims, void of agency, history, belonging, or social attachment" (Bleiker and Kay 2007, p. 149). His images perform what Martha Rosler calls "radical metonymy, with a setting implying the condition itself" (Rosler 2004, p. 195). The orphanages and the focus on the children's faces and their naked bodies represent the suffering condition itself, although the existence of the setting is indicative of unequal power relations between the photographer and the subject of his photography. The subject, especially when infants and children are regarded, has little choice in performing agency and positioning herself in the setting directed by the photographer. 
Lastly, the subject's agency is further diminished through the descriptions which link suffering with the former political regime.

The collage of stories in Mătușa's book encompasses pictures of some of the children in the doctor's care. She holds that:

Le-am făcut foarte multe fotografii copiilor pe care i-am îngrijit, și nu numai fotografii medicale. I-am pozat peste tot, acolo unde au fost alături de mine. Acum, când privesc fotografiile, îmi amintesc imediat cine e cel din poză și în ce împrejurare a fost făcută aceasta. După cum regret că nu am imortalizat multe situații și momente speciale, care vor rămâne numai în mintea mea. (Mătușa 2007, p. 42)

[I took many pictures of the children in my care, and not only medical pictures. I took pictures of them everywhere, in any place, when they were near me. Now, when I look at the photographs, I immediately remember who is in the picture and what was the context in which the picture was taken. I regret not catching more of these special moments, which will remain only in my head.]

Mătușa describes the pictures, published and unpublished, as memorializing instruments; they are tools for prolonging care even after the death of the seropositive children. While she cannot mourn for all of them individually, since hundreds have died, the doctor builds a complex environment through her book: a place where mourning and remembering can function simultaneously while the epidemic represents a topic emerging at the intersection of the political, social and medical fields. She does not restrict the number of white and black images and refuses, inherently, to essentialize one image, as it happens in Fournier's case, although the narrative remains bounded to the pediatric epidemic. The book offers a hybrid "literary picture" (Mitchel 2005, p. 31) composed of descriptions and images that pay homage to the dead in an overt manner. Mătușa's literary pictures bring forth unquantifiable and unseen relations-such as her own desire to take pictures at all times given the children's impending death-that make patients legible to doctors and to larger audiences, while localizing the spread of the epidemic inside the political regime extant in the 1990s. Thus, despite the narrative's suggestion that vulnerability was a direct result of communism and new practices of care emerged as a direct and necessary contact with North-American practitioners, it avoids fetishization, or, in Itagaki's words, exposing the visuality of vulnerability in a spectacular manner: the doctor's account allows enough space for glimpses of hope and recovery (Itagaki 2016).

Mătușa's (semi)autobiography shows that "fighting AIDS is not just a medical struggle, it involves our understanding of words and images which load the virus down with such a dismal cargo of appalling connotations" (Watney 1987, p. 3). This position opens up an intricate dialogue with Fournier's photographs, since his work brings to international attention HIV/AIDS effects on infants and children and give an image to the effects of the virus. But, both writing and photography explore to different extents the "semiotics of (...) diseases" (Gilman 1988, p. 246), meaning that they not only look at the level of overt signification, but explore more "complex confusions that permeate the image of the AIDS patient" (Gilman 1988, p. 246) and increase his or her vulnerability at the discursive, medical and political level.

Lastly, it is worth mentioning that engaging with images of infants and toddlers as the "innocent" and "deserving" victims ${ }^{17}$ underscores the epidemic's indiscriminate nature, as well as its inherent threat to the human kind. If we agree that in most cultures children and infants stand in for as metaphoric instantiations of the future, then their death enhances an all-encompassing precarious ontological position. Moreover, the politics of blame (as seen in the case of the gay and lesbian population, or the drug users) do not function when it comes to HIV positive infants and toddlers,

17 For an in-depth analysis of these terms, see Campbell (2008, pp. 80-82). 
although there is a superimposed blaming mechanism that points toward the communist regime, the nurses and the parents. The infants and the children are contagious and portrayed as such, their bodies form templates for the recognition of other seropositive individuals and are thus contained in the frame. Nonetheless, the tension between the innocent sufferer and the dangerous carrier of a virus leads to effacement, to a type of percepticide in the case of the pediatric AIDS epidemic in Romania.

\section{Conclusions}

By way of conclusion, the difficulty of representing diseases and epidemics is not a new conundrum to the medical humanities field, or to written and visual representations for that matter. But this begs the question of the exceptional nature of AIDS: is HIV/AIDS unique in its resistance to representation? Yes, and no. In general, one does not die of AIDS, but because of the opportunistic infections the immune system cannot fight off. Representing the human immunodeficiency virus or the acquired immunodeficiency syndrome becomes a complex task that risks to focus on opportunistic infections and the environment as structurally violent aspects that keep certain groups of people fixed in a specific category of disposability. The complexity of such a task is given by the concatenation between a weakened immune system that cannot perform its primary function of defense, different bacteria and viruses, opportunistic infections, poverty and sometimes lack of access to medicine, just to name a few elements. Thus, if we rehearse Treichler's argument about AIDS as an epidemic of multifarious significations, then written and photographic works may go beyond the existing epistemological tools of representation.

Moreover, AIDS has accrued over time deep political and social meanings that can be summarized, in part, through stigmatization and exclusion from the official public discourse. Thus, in order to represent it, one has to disentangle the epidemic from its imposed layers of various interpretations; AIDS is not only an epidemic, but it is something that escapes cures or immunization through vaccination. On the other hand, if we follow the idea that any illness is hard, nearly impossible, to represent in a singular manner, and one needs to employ different artistic and literary means to get to it, to attempt drawing a bigger and better picture, then we arrive at the idea that only complex art and literary forms can juxtapose the necessary entanglements for a more comprehensive conception of HIV/AIDS and its medical and non-medical history. Laura Salisbury refers to "experimental and non-realist modes of modernist texts [that] might offer a useful mode for representing illness" (Salisbury 2016, p. 5). However, this article shows that realist modes of expression still hold power when it comes to disentangling layers of meaning and representing methodologies of looking at epidemics, specifically HIV/AIDS, as instruments that perform percepticide and showcase visual vulnerability, as well as tools that open up a dialogue about the ways in which epidemics are localized, domesticated, and communicated via interrelated networks of narration and visual discourses.

Funding: This research received no external funding.

Conflicts of Interest: The author declares no conflict of interest.

\section{References}

20/20 Romanian Orphanages. 2017. Youtube. October 16. Available online: https://www.youtube.com/watch?v= ywkMLTfTcro\&t=2248s (accessed on 29 January 2019).

Adevărul. 2015. România, Singura Țară Care și-a Plătit la un Moment Dat Toată Datoria Externă. (Romania, The Only Country That Paid Its External Debt at Some Point). Available online: https://adevarul.ro/news/societate/romania-singura-tara-si-a-platit-moment-dat-datoria-externa8_56f893d55ab6550cb84cd458/index.html (accessed on 27 January 2019).

ADST. 2015. Saving a Lost Generation. The Rush to Adopt Romania's Orphans. Interview with former US ambassador to Romanian in late 1980s and early 1990s. Association for Diplomatic Studies and Training. Available online: https://adst.org/2015/04/a-lost-generation-the-rush-to-adopt-romanias-orphans/ (accessed on 28 January 2019). 
Armillas-Tiseyra, Magalí. 2018. Marvelous Autocrats: Disrupted Realisms in the Dictator Novel of the South Atlantic. In The Global South Atlantic. Edited by Kerry Bystrom and Joseph R. Slaughter. Fordham: Fordham University Press, pp. 186-204.

Bello, Gonzalo, Joana M. Afonso, and Mariza G. Morgado. 2012. Phylodynamics of HIV-1 Subtype F1 in Angola, Brazil and Romania. Infection, Genetics and Evolution 12: 1079-86. [CrossRef] [PubMed]

Bleiker, R., and A. Kay. 2007. Representing HIV/AIDS in Africa: Pluralist Photography and Local Empowerment. International Studies Quarterly 51: 139-63. [CrossRef]

Bohlen, Celestine. 1990. Upheaval in the East. Romania's AIDS Babies-A Legacy of Neglect. The New York Times. February 8. Available online: https://www.nytimes.com/1990/02/08/world/upheaval-in-the-east-romania-saids-babies-a-legacy-of-neglect.html (accessed on 28 January 2019).

Boltanski, Luc. 1999. Distant Suffering: Morality, Media, and Politics. Cambridge: Cambridge University Press.

Butler, Judith. 2002. What is Critique an Essay on Foucault's Virtue. In The Political. Edited by David Ingram. Malden: Blackwell Publishers, pp. 212-29.

Butler, Judith. 2004. Precarious Life: The Powers of Mourning and Violence. New York: Verso Books.

Campbell, David. 2008. The Visual Economy of AIDS. A Report for the AIDS, Security and Conflict Initiative. pp. 80-82. Available online: http://asci.researchhub.ssrc.org/rdb/asci-hu (accessed on 10 October 2019).

Cartwright, Lisa. 2005. Images of "Waiting Children": Spectatorship and Pity in the Representation of the Global Social Orphan in the 1990s. In Cultures of Transnational Adoption. Edited by Toby A. Volkman. Durham: Duke University Press, pp. 185-213.

Crimp, Douglas. 1992. Portraits of People with AIDS. In Cultural Studies. Edited by Lawrence Grossberg, Cary Nelson and Paula A. Treichler. New York: Routledge, pp. 117-33.

Cynn, J. Christine. 2019. Abortion and Family as HIV Prevention Strategies Kitia Tuaré's Les Gester Ou La Vie. In Literary and Visual Representations of HIV/AIDS. Fourty Years Later. Edited by Aimee Pozoski, Jennifer Lavoie and Christine Cynn. Washington, DC: Lexington Books, pp. 105-25.

Dawes, James. 1995. Narrating Disease: Aids, Consent, and the Ethics of Representation. Social Text 43: $27-44$. [CrossRef]

Decret Numărul 770. 1966. din 1 Octombrie 1966. Pentru Reglementarea Întreruperii Cursului Sarcinii. (Executive Order Number 770, October 1st 1966, Regarding the Standardization of Abortion). Available online: http://legislatie.just.ro/Public/DetaliiDocumentAfis/177 (accessed on 28 January 2019).

Ding, Huiling. 2014. Rhetoric of a Global Epidemic: Transcultural Communication about SARS. Carbondale: Southern Illinois University Press.

Doboș, Corina. 2012. Criminalizarea Avortului-Despre Condamnările Medicilor (The Criminalization of Abortion-The Condemnation of Physicians). Institutul de Investigare a Crimelor Comunismului și Memoria Exilului Românesc (Institute for Investigating the Crime of Communsim and the Memory of Romanian Exile). Available online: https://www.iiccr.ro/criminalizarea-avortului-despre-condamnarile-medicilor/ (accessed on 28 January 2019).

Engelmann, Lukas. 2016. Photographing AIDS: On Capturing a Disease in Pictures of People with AIDS. Bulletin of the History of Medicine 90: 250-78. [CrossRef] [PubMed]

Fournier, Frank. 1990. World Press Photograph Contest. Available online: https://www.worldpressphoto.org/ collection/photo/1991/33408/5/1991-Frank-Fournier-GNS1-EJ (accessed on 12 January 2019).

Gillie, Oliver. 2019. Secret Suffering of Ceausescu's Babies: The Plight of HIV-Positive Orphans in Romania. The Independent. Available online: https://www.independent.co.uk/news/world/nicolae-ceausescu-hiv-aidsorphans-romania-revolution-pages-from-history-archive-a8764036.html (accessed on 29 March 2019).

Gilman, Sander L. 1988. Disease and Representation: Images of Illness from Madness to AIDS. Ithaca: Cornell University Press.

Hooper, Edward. 1990. Slim: A Reporter's Own Story of HIV/AIDS in East Africa. London: The Bodley Head.

Horne, A. D. 1989. Debts Paid, Romania Says. The Washington Post. April 14. Available online: https://www.washingtonpost.com/archive/politics/1989/04/14/debts-paid-romania-says/89557c5f9f4d-4810-8e15-91538f134a3f/?noredirect=on\&utm_term=.a2803f42b0a7 (accessed on 27 January 2019).

Hunt, Kathleen. 1991. The Romanian Baby Bazaar. The New York Times. March 24. Available online: https: //www.nytimes.com/1991/03/24/magazine/the-romanian-baby-bazaar.html (accessed on 28 January 2019).

Itagaki, Lynn Mie. 2016. Proximal Subjects: Framing the Bystander and the Visuality of Vulnerability. Prose Studies 38: 93-115. [CrossRef] 
Kligman, Gail. 1998. The Politics of Duplicity: Controlling Reproduction in Ceausescu's Romania. Berkeley: University of California Press.

Manolescu, Loredana S. C., Aura Temereanca, and Simona Ruţă. 2013. HIV-1 Circulating Subtypes in Romania. Roumanian Archives of Microbiology and Immunology 72: 121-34. [PubMed]

Matei, Tudor. 1989. Ceaușescu anunță că a plătit toată datoria externă a țării, de 21 miliarde de dolari: De azi înainte, România nu mai plătește tribut nimănui! (Ceaușescu Announces the Country's External Debt Has Been Paid in Full, 21 Billion Dollars: From Now On, Romania Will Stop Paying Tribute). Active News. April 12. Available online: https://www.activenews.ro/economie/12-aprilie-1989.-Ceausescu-anunta-ca-a-platit-toata-datoriaexterna-a-tarii-de-21-miliarde-de-dolari-De-azi-inainte-Romania-nu-mai-plateste-tribut-nimanui-150309 (accessed on 27 January 2019).

Mătușa, Rodica. 2007. Nobody's Angels. My Life Alongside Children Living with AIDS. Bucharest: Compania.

Mendel, Gideon. 2008. The Visual Economy of AIDS. A Report for the AIDS, Security and Conflict Initiative. Available online: http://asci.researchhub.ssrc.org/rdb/asci-hu (accessed on 10 October 2019).

Mirzoeff, Nicholas. 2011. The Right to Look: A Counterhistory of Visuality. Durham: Duke University Press.

Mitchel, W. J. T. 2005. What Do Pictures Want. The Lives and Loves of Images. Chicago: University of Chicago Press.

Nelson, Charles A., Nathan A. Fox, and Charles H. Zeanah. 2014. Forgotten Children: What Romania Can Tell Us About Institutional Care. The Donaldson Adoption Institute. December. Available online: https://www. adoptioninstitute.org/news/forgotten-children-what-romania-can-tell-us-about-institutional-care/ (accessed on 29 January 2019).

Popovici, F., R. C. Apetrei, L. Zolotusca, N. Beldescu, A. Calomfirescu, Z. Jezek, D. L. Heymann, A. Gromyko, B. S. Hersh, and M. J. Oxtoby. 1991. Acquired Immunodeficinecy Syndrome in Romania. Lancet 338: 645-49. [CrossRef]

Rosler, Martha. 2004. Decoys and Disruptions. Selected Writings, 1975-2001. New York: International Center of Photography.

Salisbury, Laura. 2016. Aphasic Modernism. Languages for Illness from a Confusion of Tongues. In The Edinburgh Companion to the Critical Medical Humanities. Edited by Jane Macnaughton, Jennifer Richards, Anne Whitehead and Angela Woods. Edinburgh: Edinburgh University Press, pp. 444-63.

Sheehan, Tanya. 2011. Doctored: The Medicine of Photography in Nineteenth-Century America. State College: Pennsylvania State University Press.

Sontag, Susan. 2004. Regarding the Pain of Others. New York: Picador.

Sturken, Marita. 1997. Tangled Memories: The Vietnam War, the AIDS Epidemic, and the Politics of Remembering. Berkeley: University of California Press.

Sturken, Marita, and Lisa Cartwright. 2009. Practices of Looking: An Introduction to Visual Culture. New York: Oxford University Press.

Taylor, Diana. 1997. Disappearing Acts: Spectacles of Gender and Nationalism in Argentina's "Dirty War". Durham: Duke University Press.

Taylor, Diana. 2003. The Archive and the Repertoire: Performing Cultural Memory in the Americas. Durham: Duke University Press.

Taylor, Diana. 2007. Double-Blind: The Torture Case. Critical Inquiry 33: 710-33. [CrossRef]

Treichler, Paula. 1999. How to Have Theory in an Epidemic: Cultural Chronicles of AIDS. Durham: Duke University Press.

Watney, Simon. 1987. Policing Desire: Pornography, AIDS and the Media. Minneapolis: University of Minnesota Press. When Ignorance Is Lethal. 2012. The Economist. April 7. Available online: https://www.economist.com/easternapproaches/2012/04/07/when-ignorance-is-lethal (accessed on 26 January 2019).

(C) 2020 by the author. Licensee MDPI, Basel, Switzerland. This article is an open access article distributed under the terms and conditions of the Creative Commons Attribution (CC BY) license (http://creativecommons.org/licenses/by/4.0/). 